\title{
SANKSI ADAT TERHADAP KRAMA DESA YANG MELAKUKAN WANPRESTASI DALAM PENGEMBALIAN KREDIT PADA LEMBAGA PERKREDITAN DESA DI DESA ADAT KAPAL
}

\author{
Anak Agung Ngurah Dharma Bayu Subandi, Anak Agung Sagung Laksmi Dewi, \\ Ni Made Puspasutari Ujianti \\ Fakultas Hukum Universitas Warmadewa, Denpasar-bali, Indonesia \\ Ajungbayu22@gmail.com, Laksmiidewi29@gmail.com, puspasutari.fhwjurnal@gmail.com
}

\begin{abstract}
Abstrak
Bank sebagai pemberi kredit seyogianya percaya kepada nasabahnya dalam jangka waktu yang disepakati akan dikembalikannya seluruh kredit yang telah diajukan. Dalam prakteknya, banyak nasabah yang tidak menepati waktu yang dijanjikan untuk mengembalikan pinjamannya. Dengan berbagai alasan, Wanprestasi disebabkan karena kurangnya kesadaran debitur akan kewajibannya yang bersifat mengikat. Penelitian ini bertujuan untuk mengetahui faktor-faktor yang menyebabkan terjadinya wanprestasi dalam pengembalian kredit pada lembaga perkreditan Desa Adat Kapal, dan untuk mengetahui penyelesaian wanprestasi dalam pengembalian kredit pada lembaga perkreditan Desa Adat Kapal. Jenis penelitian yang digunakan adalah jenis penelitian empiris, dimana penelitian ini dilakukan sesuai dengan keadaan nyata suatu kelompok masyarakat atau lingkungan sekitar dengan tujuan untuk menemukan fakta-fakta atau permasalahan hukum yang ada. Hasil penelitian ini menunjukkan bahwa faktor penyebab terjadinya wanprestasi kredit bermasalah secara umum adalah semua kredit mengandung risiko tinggi. Kredit bermasalah adalah kredit-kredit yang mengandung kelemahan atau tidak memenuhi standar kualitas yang telah ditetapkan oleh bank. Kemudian, penyelesaian wanprestasi secara adat di Lembaga Perkreditan Desa Adat Kapal didasari pada Pasal 8 perjanjian Kredit Lembaga Perkreditan Desa Adat Kapal.
\end{abstract}

Kata Kunci: Perjanjian; Lembaga Pengkreditan Desa (LPD); Wanprestasi

\begin{abstract}
Banks as credit providers should trust their customers within the agreed period of repayment of all credit that has been submitted. In practice, many customers do not fulfill the promised time to repay their loans. For various reasons, Default is caused the debtor's lack of awareness of his binding obligations. This study aims to determine the factors that lead to default in returning credit at the Desa Adat Kapal credit institution, and to determine the settlement of default in returning credit at the Desa Adat Kapal credit institution. The type of research used is the type of empirical research, where this research is carried out in accordance with the real situation of a community group or the surrounding environment in order to find facts or existing legal problems. The results of this study indicate that the factors causing non-performing loans in general are that all loans carry a high risk. Non-performing loans are loans that contain weaknesses or do not meet the quality standards set by the bank. Then, the settlement of defaults according to custom at the Ship Traditional Village Credit Institution is based on Article 8 of the Traditional Ship Village Credit Institution agreement.
\end{abstract}

Keywords: Agreement; Village Credit Institution (LPD); Default

\section{PENDAHULUAN}

Lembaga Perkreditan Desa (LPD) saat ini memang sangat membantu keuangan pada setiap desa yang ada di Bali, dibentuknya suatu lembaga perkreditan desa disini digunakan sebagai lembaga pengelola keuangan desa yang bisa mengelola untuk lebih memajukan pembangunan di desa serta membantu meningkatkan perekonomian desa (Atmadja, 2011; Putra, 2014). Namun lembaga perkreditan desa tidak semua yang bisa berjalan dengan lancar, itu disebabkan karena kredit yang dikeluarkan ada yang berjalan lancar dan ada juga yang mengalami kemacetan sehingga saat pengembalian dana tersebut 
mengalami hambatan. Maka dari itu dari pihak lembaga perkreditan desa ataupun dari pihak warganya seharusnya menggunakan suatu prinsip transparan agar permasalahan yang ada bisa diatasi secara bersama dan tidak merugikan lembaga sehingga pertumbuhan pembangunan dan peningkatan perekonomian warga juga tidak terhambat.

Perjanjian merupakan suatu kesepakatan yang dibuat oleh dua pihak atau lebih yang dibuat berdasarkan dengan peraturan perundang-undangan yang berlaku. Kesepakatan tersebut dibuat dan dituangkan dalam bentuk perjanjian, sehingga akibat perjanjian tersebut kedua belah pihak yang membuatnya telah mengikat kan dirinya untuk saling melengkapi hak dan kewajibannya, perikatan tersebut merupakan hukum bagi para pihak yang membuatnya (Bukido, 2008; Pratama, 2016). Yang apabila salah satu pihak melanggar perjanjian tersebut makan dikatakan wan prestasi atau ingkar janji. Kredit merupakan pemberian pinjaman uang atau penyediaan sejumlah uang yang diberikan berdasarkan kesepakatan pihak bank dengan pihak nasabah atau peminjam uang dan dengan keputusan dari pihak bank dengan dibuatnya suatu perjanjian pinjam-meminjam dan pihak peminjam atau nasabah diwajibkan melunasi dalam jangka waktu yang telah disepakati dan pihak nasabah juga diwajibkan mengembalikan disertai dengan persentase sejumlah bunga yang telah ditentukan oleh pihak bank.

Perjanjian kredit merupakan suatu perjanjian awal atau perjanjian pokok yang dibuat oleh pihak kreditur dengan pihak debitur dimana dalam perjanjian tersebut terdapat hak dan kewajiban dari kedua belah pihak. Dalam hal kredit maka pihak kreditur berkewajiban untuk mencairkan uang apabila pihak debitur mampu memenuhi persyaratan sebagai mana yang ditentukan oleh pihak kreditur, dan pihak debitur diwajibkan untuk mengembalikan uang tersebut sesuai dengan jumlah dan jangka waktu yang disepakati oleh kedua belah pihak.Jika dilihat dari tingkat kesejahteraan desa-desa di bali, jarang sekali suatu masyarakat yang berada di desa bagian pedalaman bisa merasakan fasilitas peminjaman uang dari lembaga perbankan, oleh karena itu dibuat suatu lembaga yang dibuat oleh pemerintah provinsi bali yang disebut dengan lembaga perkreditan desa (LPD). Disini selain bisa meminjam uang, warga desa juga bisa menabung dengan mendapat sejumlah bunga yang ditentukan oleh pihak lembaga. Adanya lembaga perkreditan desa tersebut saat ini sangat bisa membantu menunjang kesejahteraan warga desanya masing-masing terutama dalam pembangunan di wilayah desa bersangkutan serta ekonomi warga desanya yang juga mengalami perkembangan. Seiring dengan berjalannya waktu, untuk mendapat payung hukum yang diakui suatu kepastian hukum dari LPD itu sendiri maka buatkanlah suatu aturan atau peraturan daerah (Perda) sebagai suatu lembaga pengelola keuangan desa yaitu suatu peraturan mengenai lembaga perkreditan desa.

Kredit adalah suatu perjanjian yang dibuat oleh pihak peminjam uang atau debitur dengan pihak yang meminjamkan uang atau disebut dengan kreditur. Dibuat suatu perjanjian tersebut artinya pihak lembaga keuangan atau pihak kreditur mempercayai apabila uangnya dipinjam oleh pihak debitur sejumlah yang diajukan dan dengan jangka waktu yang disepakati oleh kedua belah pihak. Karena dengan perjanjian tersebut artinya secara hukum kedua belah pihak telah mengikatkan dirinya apabila dikemudian hari salah satu pihak tidak memenuhi kewajiban yang telah disepakati dalam perjanjian tersebut maka dikatakan sebagai perbuatan wanprestasi atau ingkar janji. Karena pada kenyataannya sering sekali terjadi permasalahan kredit macet artinya salah satu pihak tidak memenuhi kewajiban yang telah disepakati dalam perjanjian dengan berbagai jenis alasan. Jadi disini perjanjian tersebut penting adanya, maka apabila kemudian hari terjadi permasalahan mengenai kredit macet pihak kreditur bisa mengambil suatu tindakan untuk dapat mengembalikan uang yang telah dikeluarkannya atau yang dipinjam oleh pihak debitur tersebut.

Peraturan yang berlaku bagi perjanjian diatur dalam buku III KUH Perdata yang berjudul "Tentang Perikatan". Dalam buku tersebut, ketentuan-ketentuan mengenai perjanjian terdapat dalam Bab Kedua. Hal ini karena kredit merupakan salah satu perjanjian yang bersumber dari perikatan. Pengertian perjanjian dalam Pasal 1313 KUH Perdata disebutkan "Suatu perjanjian adalah perbuatan satu orang atau lebih mengikat kan dirinya terhadap satu orang atau lebih". Rumusan diatas tampaknya kurang lengkap, karena yang mengikatkan dirinya dalam perjanjian hanya salah satu pihak saja. Padahal seringkali dijumpai perjanjian dimana kedua belah pihak saling mengikat kan diri satu sama lain yang mana kedua belah pihak sama-sama mempunyai hak dan kewajiban yang bertimbal balik. Perjanjian kredit adalah suatu perjanjian awal atau perjanjian pokok yang harus dipenuhi oleh pihak kreditur dan pihak debitur. Pada dasarnya dalam perjanjian tersebut para pihak menyanggupi hak dan kewajiban mereka masing-masing serta dengan ditunjang oleh suatu jaminan yang jumlah 
pinjamannya bisa diukur dari nilai jaminan tersebut oleh pihak kreditur dan dengan jangka waktu yang disepakati kemudian oleh kedua belah pihak.

Seringkali debitur yang diberikan kredit oleh pihak bank tidak semua memenuhi kewajibannya dalam melakukan pembayaran atau pelunasan sesuai dengan jangka waktu yang telah disepakatinya. Kenyataannya selalu ada nasabah yang lalai dan tidak dapat membayar lunas hutangnya karena isi perjanjian terasa memberatkan debitur, sehingga tidak dapat menepati prestasinya sesuai dengan perjanjian yang telah disepakati oleh kedua pihak. Pada keadaan ini nasabah telah cidera janji, tidak memenuhi kewajibannya sebagai debitur terhadap kreditur. Keadaan yang demikian dalam hukum perdata disebut wanprestasi atau ingkar janji. Wanprestasi disebabkan karena kurangnya kesadaran debitur akan kewajibannya yang mengikat. Permasalahan yang paling sering terjadi saat hutangpiutang yaitu tindakan wanprestasi. Pihak debitur disini sering sekali mengabaikan kewajibannya untuk membayar atau melunasi sejumlah uang yang dipinjam kepada pihak kreditur, hal ini sangat merugikan pihak kreditur, karena uang yang telah dikeluarkan sebagai kredit merupakan modal dari lembaga yang harus dikembalikan lagi. Sebelum terjadinya tindakan wanprestasi pihak kreditur sering sekali memberikan peringatan terlebih dahulu kepada pihak debitur sebagai tahap awal, apabila peringatan tersebut sudah beberapa kali dilakukan tetapi tidak ditanggapi maka pihak debitur dinyatakan telah melakukan tindakan wanprestasi atau ingkar janji terhadap kewajibannya serta bisa dikenakan berupa sanksi yang telah disepakati diawal perjanjian kredit tersebut dibuat.

Dari uraian pada latar belakang masalah tersebut, maka dapat ditemukan dua rumusan masalah yang dibahas dalam penelitian ini, yakni faktor-faktor yang menyebabkan terjadinya wanprestasi dalam pengembalian kredit pada lembaga perkreditan Desa Adat Kapal, dan penyelesaian wanprestasi dalam pengembalian kredit pada lembaga perkreditan Desa Adat Kapal.

\section{METODE PENELITIAN}

Suatu karya ilmiah akan tersusun secara sistematis, mempunyai arah yang jelas serta pembahasannya teratur. Jenis penelitian yang digunakan dalam penelitian ini adalah tipe penelitian hukum empiris. Penelitian hukum empiris merupakan penelitian yang berkaitan dengan hukum dan perilaku manusia. Jenis penelitian ini dilakukan dengan cara terjun langsung ke lapangan, karena penelitian hal tersebut merupakan dasar yang akan digunakan sebagai pelaksanaan riset sesuai dengan gejala empiris yang dapat diamati pada kenyataan di masyarakat. Pendekatan masalah yang digunakan dalam penelitian ini adalah pendekatan yuridis sosiologis. Pendekatan yuridis sosiologis adalah suatu penelitian yang dilakukan terhadap keadaan nyata yang terjadi di masyarakat atau di lapangan dengan tujuan untuk menemukan fakta-fakta atau permasalahan yang ada, dan menuju pada identifikasi, dan akhirnya menuju pada penyelesaian masalah.

Pemeolehan data dalam penelitian ini deilakukan dengan menggunakan data primer dan data sekunder. 1) Data primer, Data primer adalah data yang terdiri atas hasil wawancara langsung dari narasumber dan responden. Wawancara ini dilakukan sesuai dengan pedoman yang berkaitan dengan permasalahan yang diteliti yaitu tentang perbankan. 2) Data Sekunder, Data sekunder merupakan sumber data penelitian yang didapat baik secara langsung ataupun tidak langsung dalam buku arsip, dokumen-dokumen maupun data lain yang tidak diketahui oleh umum, yang terdiri dari Bahan Hukum Primer dan Bahan Hukum Sekunder termasuk juga literatur, kamus, beserta tulisan ilmiah lainnya yang berkaitan dengan pokok permasalahan yang dikaji. Dalam penelitian ini dilakukan observasi dan wawancara langsung mendatangi sebuah institusi yaitu Lembaga Perkreditan Desa Adat Kapal Selain itu, juga dilakukan wawancara dengan mengadakan tanya jawab dengan pihakpihak yang terkait langsung dengan masalah yang dibahas dan mengambil data dengan mengamati dokumen-dokumen dan arsip-arsip yang diberikan oleh pihak yang terkait, dalam hal ini pihak Lembaga Perkreditan Desa Adat Kapal.

\section{HASIL DAN PEMBAHASAN}

\section{Faktor yang Menyebabkan Terjadinya Wanprestasi dalam Pengembalian Kredit pada Lembaga Perkreditan Desa Adat Kapal}

Perjanjian merupakan suatu kesepakatan yang dibuat oleh dua pihak atau lebih dimana akibat dari perjanjian tersebut menimbulkan perikatan bagi para pihak yang membuatnya. Sering sekali dalam suatu perjanjian terjadi perbuatan yang disebut dengan tindakan wanprestasi atau ingkar janji. Wanprestasi itu sendiri merupakan suatu perbuatan dimana salah satu pihak tidak memenuhi 
kewajibannya atau ingkar janji, suatu perikatan timbul akibat dua kemungkinan yaitu, suatu perikatan yang terjadi karena kesepakatan yang dibuat oleh para pihak yang dituangkan dalam bentuk perjanjian ataupun perikatan tersebut bisa lahir karena ditentukan oleh undang-undang (Harapan, 1986). Wanprestasi adalah suatu perbuatan ingkar janji yang dilakukan oleh salah satu pihak karena tidak memenuhi kewajiban yang telah disepakati oleh pihak kreditur dengan pihak debitur (Salim, 2008). Wanprestasi atau tidak dipenuhinnya janji dapat terjadi baik karena disengaja maupun tidak disengaja (Miru, 2007) salah satu pihak baik kreditur ataupun debitur bisa dinyatakan ingkar janji atau lalai terhadap kewajibannya apabila salah satu pihak tidak memenuhi kewajibannya ataupun terlambat untuk memenuhinya (Subekti, 2007).

Apabila dianalisis berdasarkan aspek ekonomi, yang dimaksud dengan kredit adalah pencairan uang yang dilakukan berdasarkan perjanjian yang dibuat oleh pihak kreditur dengan pihak debitur berdasarkan persyaratan tertentu dari pihak kreditur dan dilengkapi oleh pihak debitur dengan menjaminkan baik benda bergerak ataupun benda tidak bergerak yang besaran jumlah pencairan tersebut dicairkan berdasarkan nilai jaminan tersebut dengan jangka waktu yang telah ditentukan dan disepakati yang kemudian kredit tersebut dibayarkan dengan cicilan setiap bulan dengan tanggal yang telah ditentukan oleh pihak kreditur (Ibrahim, 2004). Dengan kata lain jaminan yang digunakan oleh pihak debitur ditahan oleh pihak kreditur sampai kredit yang diberikan oleh pihak kreditur dilunasi oleh pihak debitur dan juga sebaliknya jaminan tersebut bisa diambil alih ataupun dilelang oleh pihak kreditur apabila pihak debitur tidak memenuhi kewajibannya untuk melunasi pembayaran kreditnya.

Dalam dunia perbankan ada yang disebut dengan kredit yang bermasalah, artinya kredit yang bermasalah tersebut membuat suatu resiko terhadap lembaga perbankan yang memberikan kredit dengan kata lain kredit tersebut tidak sesuai dengan standar yang ditetapkan oleh lembaga perbankan tertentu, sehingga dalam kredit tersebut terdapat suatu kelemahan yang bisa menimbulkan resiko kerugian bagi pihak perbankan. Pada umumnya kredit bermasalah tersebut sering timbul akibat dari SDM itu sendiri dalam hal ini yaitu disebabkan oleh pihak debitur. Pihak debitur dalam suatu kredit sering melakukan tindakan wanprestasi atau lalai terhadap kewajibannya dengan berbagai alasan salah satunya yaitu tidak adanya itikad baik dari pihak debitur dalam pembayaran baik itu karena tidak mampu atau karena memang sengaja mengulur waktu pembayarannya. Disini terlihat bahwa tidak ada sifat transparan dari pihak debitur apakah memang tidak mampu membayar atau memang tidak ada itikad baik yang sengaja dilakukannya.

Dalam undang-undang perbankan disebutkan mengenai pengertian kredit yaitu pemberian pinjaman uang atau penyediaan sejumlah uang yang diberikan berdasarkan kesepakatan pihak bank dengan pihak nasabah atau peminjam uang dan dengan keputusan dari pihak bank dengan dibuatnya suatu perjanjian pinjam-meminjam dan pihak peminjam atau nasabah diwajibkan melunasi dalam jangka waktu yang telah disepakati dan pihak nasabah juga diwajibkan mengembalikan disertai dengan persentase sejumlah bunga yang telah ditentukan oleh pihak bank. Dalam suatu kredit yang bermasalah selain ada kelemahan dari pihak nasabah, kelemahan tersebut juga bisa disebabkan dari pihak lembaga perbankan itu sendiri. Kelemahan dari pihak lembaga bisa disebabkan dari faktor internal ataupun dari faktor eksternalnya. Contoh kelemahan dari faktor internalnya yaitu adanya kepentingan pribadi dari pihak pengelola lembaga dengan mengharapkan imbalan dari nasabah dalam pencairan yang sedang diprosesnya. Pada kenyataannya yang sering terjadi yaitu pihak nasabah dengan caranya sendiri melakukan suatu tindakan atau menjanjikan suatu imbalan apabila kredit yang diajukannya bisa lolos dengan bantuan dari pihak lembaga tersebut. Dengan itu disatu sisi pihak lembaga mencari keuntungan untuk kepentingan pribadinya dan disisi lain pihak nasabah menggunakan kesempatan tersebut untuk melancarkan proses pencairan kreditnya. Sehingga pihak lembaga hanya melihat dari segi nilai imbalannya saja tanpa menganalisa lebih detail kemungkinan atau permasalahan yang bisa terjadi kedepannya contohnya seperti kemampuan bayar dari pihak nasabah. Maka pihak nasabah dengan keadaan tersebut bisa dimanfaatkan untuk pencairannya dan bisa melakukan tindakan wanprestasi.

Contoh kelemahan dilihat dari faktor eksternalnya yaitu, kemungkinan permasalahan yang akan terjadi karena adanya suatu perubahan baik itu disebabkan karena adanya bencana alam ataupun karena nasabah itu sendiri sehingga karena kejadian tersebut nasabah mengalami kerugian pada unit usahanya sehingga nasabah macet untuk melaksanakan kewajiban pembayarannya. Dalam KUHPerdata dikatakan bahwa semua orang berhak untuk mengadakan suatu perjanjian atau perikatan terhadap pihak manapun sepanjang memenuhi persyaratan sebagaimana yang disebutkan dalam 
peraturan tersebut. Perjanjian dapat digunakan dalam berbagai bidang yang dalam hal ini perjanjian untuk suatu kredit. Maka dalam suatu perjanjian kredit apabila seorang calon nasabah dapat memenuhi persyaratan sebagaimana yang telah ditentukan oleh pihak lembaga keuangan, maka nasabah tersebut berhak untuk mengajukan kredit. Dalam peraturan daerah (Perda) dinyatakan bahwa lembaga perkreditan desa (LPD) merupakan suatu lembaga pengelola keuangan milik desa adat tertentu yang diberikan untuk memfasilitasi warga desanya itu sendiri. Maka berdasarkan perda tersebut LPD hanya diperuntukan untuk warga desanya saja atau disebut krama desa. Akan tetapi pada kenyataannya LPD tidak hanya memberikan fasilitas kredit untuk warga desanya saja melainkan juga diberikan kepada warga yang tidak merupakan warga desanya. Apabila dalam hal ini bisa menguntungkan pihak LPD maka haruslah dibuat suatu perjanjian yang bukan warga desanya dilengkapi dengan jaminan, rekomendasi serta penjamin yang berasal dari desanya tersebut, perjanjian itu disebut dengan penanggung utang. Yang dimaksud dengan penanggung utang disini yaitu pihak ketiga yang menyetujui perjanjian tersebut untuk kepentingan lembaga perkreditan desa, pihak penjamin tersebut juga mengikatkan dirinya untuk menjadi penjamin dari pihak debitur, apabila suatu hari terjadi permasalahan maka pihak penanggung tersebut atau pihak ketiga yang bertanggung jawab atas permasalahan yang dilakukan oleh pihak debitur itu. Karena jika dilihat dari peraturan tentang lembaga keuangan mikro pemberian kredit kepada warga yang tidak merupakan warga desanya merupakan tindakan melanggar hukum. Oleh karena itu diperlukan pihak penjamin dari warga luar desa yang mengajukan kredit bahwa pihak peminjam kredit luar desa tersebut nantinya mampu untuk memenuhi kewajibannya melunasi kreditnya. Pihak penjamin disini bertanggung jawab atas kredit yang diberikan oleh pihak LPD tersebut, dalam hal penelitian ini terhadap Pemberian Kredit bagi nasabah pada LPD Kapal.

\section{Penyelesaian Wanprestasi dalam Pengembalian Kredit Pada Lembaga Perkreditan Desa Adat Kapal}

Penyelesaian kasus Wanprestasi secara adat di Lembaga Perkreditan Desa Adat Kapal didasari pada Pasal 8 perjanjian Kredit Lembaga Perkreditan Desa Adat Kapal dan pasal 2 dan pasal 5v Peraturan Daerah No.3 Tahun 2007 Tentang Lembaga Perkreditan Desa. Langkah - langkah yang dilakukan oleh Kepala Bagian Kredit LPD Desa Pakraman Kapal adalah menghubungi nasabah melalui telepon untuk memberitahukannya bahwa pembayaran terhadap pokok maupun bunga kredit telah jatuh tempo. Jika telah dihubungi melalui telepon namun nasabah tidak juga melunasi kewajibannya, maka akan diberikan Surat Pemberitahuan Tagihan Tertunggak. Namun jika berturut turut selama 3 (tiga) bulan nasabah belum juga melakukan pembayaran, maka diberikan Surat Peringatan I (SP.I), peringatan ini berupa permintaan dari pihak LPD kepada nasabah untuk segera membayar kewajibannya yang telah jatuh tempo. Begitu juga seterusnya, jika nasabah tetap tidak melakukan pembayaran atau tidak memenuhi kewajibannya selama 6 (enam) bulan berturut - turut akan diberikan Surat Peringatan II (SP.II), dan jika tidak melakukan pembayaran selama 9 (Sembilan) bulan berturut-turut, maka pihak LPD akan memberikan nasabah Surat Peringatan III (SP.III), agar segera melakukan pembayaran. Pembayaran ini berupa permintaan dari pihak LPD kepada nasabah untuk segera membayar kewajibannya yang telah jatuh tempo.

Menurut hasil wawancara saya dengan Bapak I Wayan Suanda selaku bagian kredit di Lembaga Perkreditan Desa Adat Kapal pada tanggal 30 Juli 2020 pukul 11.00 Wita, menyatakan bahwa prinsip 5C pada Lembaga Perkreditan Desa sangat penting dan sangat berperan dalam menilai apakah layak untuk memberikan debitur dana sehingga tidak melakukan wanprestasi dikemudian hari. Rencana Pemberian sanksi adat salah satu kriteria awig - awig Desa Adat Kapal yaitu Palet 2 indik pamidanda pawos 144 pada tahun 2011 kepada debitur I Made Sujaya yang tidak berusaha dan mempunyai itikad baik dalam pengembalian kreditnya memang pilihan terakhir yang diberikan oleh Desa Pakraman Kapal. Pemberian sanksi pada I Made Sujaya berupa dicabutnya seluruh hak adatnya Menurut I Made Ladra selaku ketua dewan pengawas yang juga bendesa adat, menyatakan bahwa I Made Sujaya pada paruman adat menyatakan bahwa yang bersangkutan benar tidak mampu lagi memenuhi kewajibannya melunasi kreditnya. Penyebab lain kenapa I Made Sujaya mengaku menyerah dan menyatakan tidak mampu untuk melunasi kredit serta menerima sanksi yang diberikan, menurut Ketua Dewan Pengawas I Made Ladra menyatakan bahwa selama ini seluruh keluarga I Made Sujaya telah menetap di Denpasar. 


\section{SIMPULAN DAN SARAN}

\section{Simpulan}

Dari penjelasan pendahuluan sampai dengan hasil penelitian dan pembahasan, maka dapat disimpulkan bahwa faktor yang menyebabkan terjadinya wanprestasi dalam pengembalian kredit pada lembaga perkreditan Desa Adat Kapal yakni, Kelemahan dari sisi intern debitur dapat disebabkan karena menurunnya usaha debitur mengakibatkan turunnya kemampuan debitur untuk membayar angsuran dan kelemahan dari sisi internal bahwa pihak lembaga keuangan tidak mampu untuk membina debiturnya sehingga debitur menggunakan kesempatan tersebut sebagai celah melakukan tindakan wanprestasi dan juga terdapat kelemahan dari sisi eksternal. Kemudian, penyelesaian wanprestasi dalam pengembalian kredit pada Lembaga Perkreditan Desa Adat Kapal yakni, Memberitahukan kepada peminjam yang sudah lewat dari tanggal jatuh tempo serta membuat surat teguran pertama,membuat surat teguran kedua,membuat surat peringatan pertama,membuat surat peringatan kedua,membuat somasi dan melakukan eksekusi.

\section{Saran}

Adapun saran yang hendak disampaikan berdasarkan hasil penelitian ini, yaitu pihak Lembaga Perkreditan Desa Adat Kapal seharusnya melakukan langkah untuk melihat situasi keadaan keuangan atau usaha dari Debitur sehingga tidak ada masalah yang dapat merugikan Lembaga Perkreditan Desa di saat Debitur tidak dapat melakukan pembayaran atau melakukan Wanprestasi. Kemudian, pihak lembaga kiranya lebih menekankan ketentuan yang ada di saat penyelesaian kasus Wanprestasi, Lembaga Perkreditan Desa lebih berani melakukan eksekusi jaminan debitur dan juga pihak Lembaga Perkreditan Desa harus berani menggunakan awig - awig desa untuk memberi efek jera kepada debitur.

\section{DAFTAR PUSTAKA}

Atmadja, A. T. (2011). Penyertaan Modal Sosial dalam Struktur Pengendalian Intern Lembaga Perkreditan Desa (LPD). Jurnal Ilmuiah Akuntansi Dan Humanika, 1(1).

Bukido, R. (2008). Urgensi Perjanjian dalam Hubungan Keperdataan. Jurnal Ilmiah Al-Syir'ah, 6(1). Harapan, Y. (1986). Segi-segi Hukum Perjanjian (Cetakan Ke). Alumni.

Ibrahim, J. (2004). Cross Default \& Cross Collateral dalam Upaya Penyelesaian Kredit Bermasalah. PT Refika Aditama.

Miru, A. (2007). Hukum Kontrak dan Perancangan Kontrak. Rajawali Pers.

Pratama, G. N. (2016). Kekuatan Hukum Memorandum of Understanding (MoU) dalam Hukum Perjanjian di Indonesia. Veritas et Justitia, 2(2), 424-440.

Putra, B. P. (2014). Pengelolaan Resiko Pada Organisasi Lembaga Perkreditan Desa. Citizen Charter, $1(1), 1-24$.

Salim, H. S. (2008). Pengantar Hukum Perdata Tertulis (BW). Sinar Grafika.

Subekti. (2007). Kitab Undang-Undang Hukum Perdata. PT. Arga Printing. 